\title{
Comparative Study of Toxicological Impinge of Glyphosate and Atrazine (Herbicide) on Stress Biomarkers; Blood Biochemical and Hematological Parameters of the Freshwater Common Carp (Cyprinus carpio)
}

\author{
Ahsan Khan ${ }^{1 *}$, Nazish Shah ${ }^{1}$, Anum Gul', Najmu-Us-Sahar ${ }^{1}$, \\ Afshan Ismail ${ }^{1}$, Muhammad $^{2}$, Fawad Aziz', Muhammad Farooq ${ }^{2}$, \\ Muhammad Adnan ${ }^{3}$, Muhammad Rizwan ${ }^{4}$ \\ ${ }^{1}$ Department of Zoology, University of Swabi, Khyber Pakhtunkhwa (KP), Pakistan \\ ${ }^{2}$ Department of Microbiology, University of Swabi, Khyber Pakhtunkhwa (KP), Pakistan \\ ${ }^{3}$ Department of Agriculture, University of Swabi, Khyber Pakhtunkhwa (KP), Pakistan \\ ${ }^{4}$ Center of Biotechnology and Microbiology, University of Peshawar, Khyber Pakhtunkhwa, Pakistan
}

Received: 30 March 2016

Accepted: 16 April 2016

\begin{abstract}
The purpose of the present study was to scrutinize the effect of glyphosate and atrazine (herbicide) on blood biochemical and hematological parameters of common carp, (Cyprinus carpio), including plasma glucose (RBS), cholesterol (CH), serum protein (SP), creatinine phosphates (CPK), lactate dehydrogenase (LDH), WBC, hemoglobin (Hb), platelets (PT), lymphocytes (LP), monocytes (MT), esinophils (EN), and neutrophils (NT), and on behavioral aspects for $(24,48,72,96)$ hours under doses of $(0.1,0.07,0.05,0.02)$ and $(0.2,0.15,0.1,0.05) \mathrm{mlL}-1$ respectively of glyphosate and atrazine. For analysis of biochemical and hematological parameters, the protocol of biochemical analyzer set (Merck Micro Lab 300 biochemistry analyzer) and hematological analyzer (Mindray BC-2300 Hematology Analyzer) was followed in the laboratory. An upturn in RBS, CH, and WBC concentration was observed while SP, LDH, LT, MT, and EP concentrations were decreased against both herbicides. $\mathrm{CPK}$ and $\mathrm{Hb}$ concentrations were increased against atrazine, while against glyphosate the concentrations were decreased. PT and NT showed momentous upturn in concentrations against glyphosate, while showing a decline against atrazine. Both herbicides affected the blood biochemical and hematological parameters of the selected fish. Behaviorally, changes were observed
\end{abstract}

*e-mail: Ahsanyousafzai27@yahoo.com 
against both herbicides, including loss of equilibrium, increase in the frequency of opercular movements, fast swimming and jumping, losing balance, becoming exhausted and lethargic, vertical swimming, and bleeding at the base of the eyeballs.

Keywords: glyphosate, atrazine, total protein, glucose, white blood cells

\section{Introduction}

The bioaccumulative and non-biodegradable nature of herbicides are serious threats to aquatic organisms, but herbicides are utilized because they are considered an integral part of modern agricultural systems [1]. Agriculture production can be improved by the use of these herbicides, but unfortunately they may reach nontargeted areas and can impact non-target organisms, especially aquatic species and their environments [2]. Environmental toxicology studies have confirmed that herbicides affect non-target species in the environment because these substances are not fully selective and they are applied to crops in large amounts, only a small portion of which reaches the target and the remaining portion affects non-targeted areas such as wildlife, birds, domesticated animals via grazing, soil microorganisms, adherence of herbicide particles to wind (thus contributing to wind pollution), and aquatic organisms (particularly fish) - causing effects like; reducing biodiversity, altering reproductive and behavioral responses, altering physical and chemical composition of aquatic bodies (which in turn alter the hematological and biochemical parameters of fish), increasing disease susceptibility, and accumulating toxic substances that can reach humans through the food chain, thus affecting humans as well [3-5].

Fish can be used to detect and document pollutants released into their environment. Several studies have demonstrated that glyphosate is toxic to fish and can give rise to morph functional changes in these animals. Strong evidence shows negative outcomes from glyphosate exposure, including neurological and birth defects, fetal death, and neurodevelopment [6-16]. Different studies have been conducted on atrazine effects on fish, including ATZ effects on hematological parameters, locomotor activity, immune response, metabolism, oxidative stress, osmoregulatory disturbance and reproduction [17-21].

So in accordance with these studies, the present study was designed to evaluate glyphosate and atrazine herbicide impingement on hematological and biochemical parameters of the freshwater fish common carp (Cyprinus carpio).

\section{Methods and Materials}

\section{Experimental Fish} and their Maintenance

Healthy and active specimens of common carp (Cyprinus carpio) were procured from the Attock and
Mardan hatchery each month from March to June, 2015, and were carefully analyzed and treated with $0.2 \%$ $\mathrm{KMnO}_{4}$ solution for two minutes to get rid of any dermal infections, and then were transferred to an acclimatization tank containing tapwater for two weeks for acclimatization purposes. The fish were then transferred to experimental tanks containing tapwater for experimentation. They were fed properly with commercial food on every alternate day in both acclimatization and experimental tanks. $\mathrm{PH}$ and temperature of the water in both tanks were kept constant and checked every alternate day. Other parameters were additionally checked in both acclimatization and experimental tanks, including total hardness, calcium hardness, magnesium hardness, water conductivity, dissolved oxygen, total solids, total dissolved solids, total suspended solids, total alkalinity, and chloride, with concentrations of $95 \mathrm{mg} / \mathrm{l}, 61.6 \mathrm{mg} / \mathrm{l}, 35 \mathrm{mg} / \mathrm{l}$, $431 \mu \mathrm{S} / \mathrm{cm}, 7.37 \mathrm{ppm}, 321 \mathrm{mg} / \mathrm{l}, 221 \mathrm{mg} / \mathrm{l}, 100 \mathrm{mg} / \mathrm{l}$, $163.3 \mathrm{mg} / \mathrm{l}$, and $20.3 \mathrm{mg} / \mathrm{l}$, respectively, indicating that all of these parameter concentrations were in the normal range.

\section{Experimental Design}

For experimentation purpose, one group was considered as control group consisted of five fish and kept without treatment. Acute toxicity analysis of atrazine and glyphosate herbicide; 52 fish were taken; 26 for analysis of acute toxicity of atrazine and 26 for analysis of acute toxicity of glyphosate herbicide. 08 groups were made that are 04 groups for analysis of acute toxicity of atrazine and 04 groups for analysis of acute toxicity of glyphosate. In both cases, Groups 1 and 2 consisted of five fish each treated with a atrazine dose of 0.2 and $0.15 \mathrm{mlL}^{-1}$ and glyphosate dose of 0.1 and $0.07 \mathrm{mlL}^{-1}$ for 24 and $48 \mathrm{hrs,}$ respectively. Groups 3 and 4 consisted of eight fish each, which were processed under atrazine dose of 0.1 and $0.05 \mathrm{mlL}^{-1}$ and glyphosate dose of $0.05,0.02 \mathrm{mlL}^{-1}$ for 72 and 96 hrs, respectively.

\section{Blood Collection and Preservation}

Blood samples were collected from the freshly anesthetized fish immediately. The chemical MS 222 was used as an anesthetic agent. Blood samples were collected by puncturing the caudal vein of fish and sometimes from direct puncturing of their hearts. Blood was collected with the help of hypodermic syringes that were heparinized to prevent clotting of blood and stored in test tubes [2223]. All the biochemical parameters were determined by subjecting blood for centrifugation (Micro Refrigerated 
Centrifuge $3,000 \mathrm{rpm}$ ) to separate the serum. The serum was collected and was allowed to determine the biochemical and hematological parameters.

\section{Methods of Biochemical and Hematological Parameter Estimations}

For analysis of biochemical parameters, the biochemical analyzer set (Merck Micro Lab 300 biochemistry analyzer) protocol was followed, while for analysis of hematological parameters we followed the protocol of a Mindray BC-2300 hematology analyzer.

\section{Results and Discussion}

The control group concentrations of plasma glucose (RBS), cholesterol $(\mathrm{CH})$, serum protein $(\mathrm{SP})$, creatinine phosphates (CPK), lactate dehydrogenase (LDH), WBC, hemoglobin $(\mathrm{Hb})$, platelets (PT), lymphocytes (LP), monocytes (MT), esinophils (EN), and neutrophils (NT) were $33 \mathrm{mmo1} / 1,82 \mathrm{mmo} 1 / 1,5.53 \mathrm{mmol} / 1,101 \mathrm{mmo} 1 / 1$, $78.3 \mathrm{mmol} / 1, \quad 2.27 \mathrm{mmol} / 1,5.46 \mathrm{mmol} / 1,13000 \mathrm{mmol} / 1$, $39.3 \%, 6 \%, 4 \%$, and $50 \%$, respectively.

\section{Blood Biochemical and Hematological Parameters Concentration Observed after Treatment}

Plasma glucose concentrations for groups 1-4 were 30.6, 44, 50, and $72.3 \mathrm{mmol} / 1$, respectively, against glyphosate herbicide, while against atrazine plasma glucose the concentrations were $32,40,45$, and $58 \mathrm{mmol} / \mathrm{l}$, respectively (Figs 1-2). An upturn in plasma glucose concentration was observed against both herbicides. More increased concentrations against glyphosate were observed as compared to against atrazine. Elevated concentrations of plasma glucose could be explained as a result of the conversion of glycogen to glucose to cope with the stress of environmental conditions induced by the pollutants. Also, the hyperglycemic state could be explained as a result of the increased secretion of catecholamine from the adrenal medulla, which in turn enhances the breakdown of glycogen and increases the level of blood glucose and corticosteroids as a stress response of fish exposed to these herbicides. According to [24], the increase in glucose levels in pollutant-exposed fish may also be due to the degranulation and vacuolization of the pancreatic alpha cells in the initial stages and damage of beta cells in later stages. According to [25], fish exposed to acute and chronic concentrations of thiobencarb showed a significant increase of serum glucose concentration.

Cholesterol concentrations for groups 1-4 were 58.6, 84, 88, and $92 \mathrm{mmol} / \mathrm{l}$, respectively, against glyphosate herbicide, while against atrazine cholesterol the concentrations were $60,88,95$, and $102 \mathrm{mmol} / \mathrm{l}$, respectively (Figs 1-2). Cholesterol concentrations first declined but then increased in the last three treated groups against both herbicides. Environmental stress conditions caused a decline in concentrations of plasma glucose.
Fish need energy to overcome stress, so for this purpose protein catabolism and then lipid contents catabolism occurred, causing cholesterol concentration to decline for the purpose of matching the needed energy during stressful conditions [26]. More declines were observed against glyphosate, while on other hand against atrazine the glucose level is reduced on a small scale, so to overcome the need of energy less lipid profile is utilized. However, the inclined concentrations of cholesterol on the remaining days were due to the accumulation of herbicides in the liver, disrupting lipid metabolism and increasing serum cholesterol levels [27]. A decline in the concentration of cholesterol was in accordance with the findings of [28], which observed the effect of cadmium on biochemical contents (cholesterol) in liver and ovaries of Garra Malaya, and found that a substantial decrease in cholesterol and stated that this may be due to general damage. Findings of inclined concentrations were in accordance with [29], which exposed Clarias garipinus dithiopyr catfish to toxicants and found increases in cholesterol concentrations as compared to the control group. The increase of total plasma lipids may be due to the increase of lipid peroxide formations induced by the effect of herbicides, as previously reported by [29].

Serum protein concentrations for groups 1-4 were 2.2, $2.6,3.2$, and $3.8 \mathrm{mmol} / 1$, respectively, against glyphosate herbicide, while serum protein concentration against atrazine was $2.8,3.6,3.8$, and $4.0 \mathrm{mmol} / \mathrm{l}$, respectively, as shown in Figs 1 and 2. Protein concentrations against both herbicides declined. A greater decline in protein concentrations against glyphosate was observed as compared to against atrazine. The reduction in serum protein concentration could be attributed to the adjustment of the fish to its new environmental conditions as a result of stress response [30]. According to [31], the decrease of total muscle protein in thiobencarb-exposed fish is due to the reduction in food consumption and/or decrease in

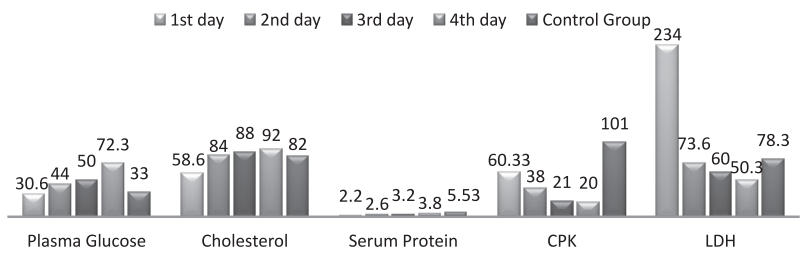

Fig. 1. Comparison of biochemical parameter concentrations between control group and treated groups against glyphosate.

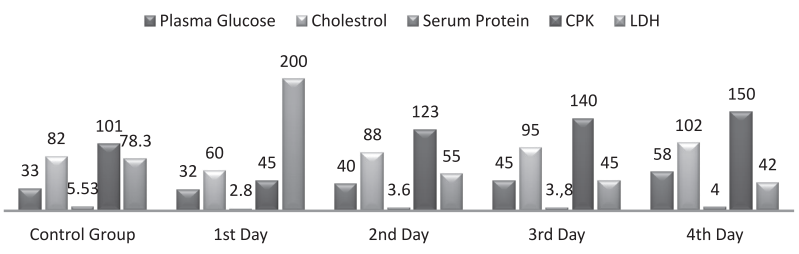

Fig. 2. Comparison of Biochemical parameter concentrations between control group and treated groups against atrazine. 
gross food conversion, or the decrease in insulin levels as detected by the observed higher plasma glucose level in thiobencarb-exposed fish. According to [32], who declare that it is obvious that exposure of fish for a long time to most toxicants (including herbicides) interferes with protein metabolism, and in their experiment decreased protein levels were reported in glyphosate-treated fish, which they attributed to stress-mediated immobilization of these compounds, leading to an increase in energy demands by the fish to cope with environmental conditions caused by the toxicant. According to [33], the higher energy demand might have triggered an increase in protein catabolism, a process in which both blood and structural proteins are converted to energy, thereby reducing serum protein.

LDH concentrations for groups 1-4 were 234, 73.6, 60 , and $50.3 \mathrm{mmo1} / 1$, respectively, against glyphosate herbicide, and against atrazine, LDH concentrations were 200, 55, 45, and $42 \mathrm{mmol} / \mathrm{l}$, respectively (Figs 1 and 2). Against both herbicide LDH concentration showed an increase against first-day exposure, while on remaining days LDH concentrations slowly and gradually started decreasing. LDH is the terminal enzyme of anaerobic glycolysis and therefore of crucial importance in muscle physiology, particularly in conditions of chemical stress when high levels of energy may be required for a short period of time [34]. The increase in LDH level indicated metabolic changes, i.e., glycogen catabolism and a glucose shift towards the formation of lactate, primarily in muscle. The increase of LDH activity in the whole body extract of fish was a physiological mechanism to provide more energy to deal with the effects of any stress condition [35]. Similar changes in LDH activity were observed in crayfish exposed to endosulfan [36]. Increased LDH activity in the gill and brain of tilapia, Oreochromis mossambicus (after exposure to monocrotophos) was reported by [37]. The present study agrees with [38], who stated that the increased enzymatic activities in the liver might be due to increased enzyme synthesis to counter the damage caused by toxicants. The observed increase of LDH activity can be attributed to the conversion of accumulated pyruvate into lactate, which is transported through muscle to hepatopancreas and regenerated glucose and glycogen to supply energy for fish exposed to insecticides. Similar results have been reported by [39-41]. Decreased concentrations were attributed to the hepatocellular damage and inhibition of enzyme synthesis as a result of the toxic effects of the herbicide [36-35].

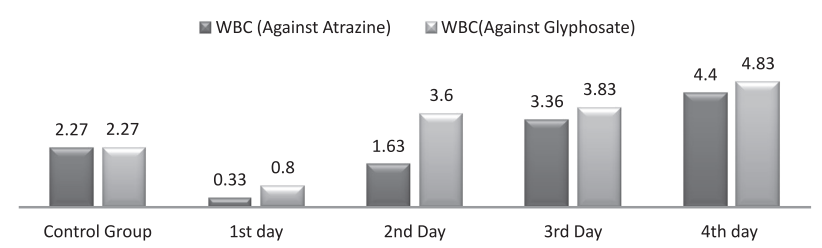

Fig. 3. Comparison of WBC concentrations between control group and treated groups against atrazine and glyphosate.

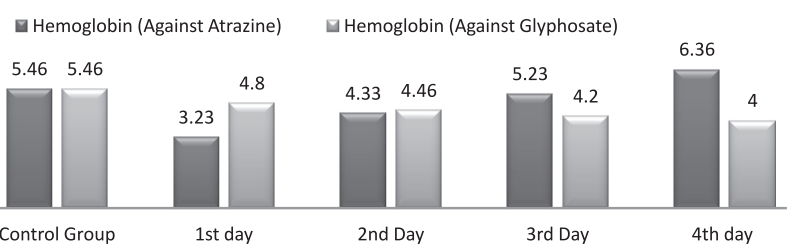

Fig. 4. Comparison of hemoglobin concentrations between control group and treated groups against atrazine and glyphosate.

CPK concentrations against glyphosate were $60.33,38,21$, and $20 \mathrm{mmol} / 1$, while against atrazine concentrations were $45,123,140$, and $150 \mathrm{mmol} / 1$, respectively (Figs 1-2). CPK against glyphosate showed a continuous decline, while against atrazine the decline in concentration was noticed on day one, and increased concentrations were observed on the remaining days of exposure. The decreased activities of CPK may be attributed to decreased enzyme synthesis, or it may also be due to changes in permeability of hepatic cells. According to [38], the decrease activity of enzyme is due to the inhibition of these enzymes because of the effect of the toxicant, which shows the adverse effect of aquatic pollution on fish health. Similarly, the incline in CPK concentration reveals that the main hepatic cellular component to be affected by the ambient toxicants seems to be the cell membrane, and such aquatic toxicants have increased membrane permeability, leading to enhanced leaching out of the enzymes [35].

WBC concentrations for groups 1-4 were 0.8, 3.6, 3.83 , and $4.83 \mathrm{mmo1} / 1$, respectively, against glyphosate herbicide, while WBC concentrations against atrazine were $0.33,1.63,3.36$, and $4.4 \mathrm{mmol} / \mathrm{l}$, respectively (Fig. 3). Against both herbicides, WBC concentrations declined on the first day, while remaining days saw a significant increase in concentrations against both herbicides. Exposure of fish to sub-lethal concentrations of copper for 15,30 , and 45 days caused significant alterations in hematological parameters of the Indian freshwater fish Channa punctatus, and WBC counts in their work were found to significantly increase as compared to control [42]. High white blood cell counts indicate damage due to infection of body tissues, severe physical stress, and leukemia [43-44].

$\mathrm{Hb}$ concentrations for groups 1-4 were 4.8, 4.46, 4.2 , and $4.0 \mathrm{mmol} / 1$, respectively, against glyphosate herbicide, while against atrazine $\mathrm{Hb}$ concentrations were

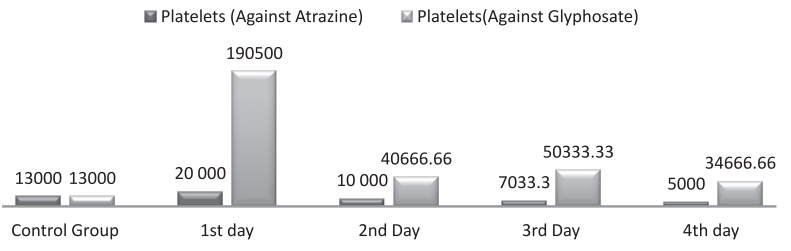

Fig. 5. Comparison of platelet concentrations between control group and treated groups against atrazine and glyphosate. 


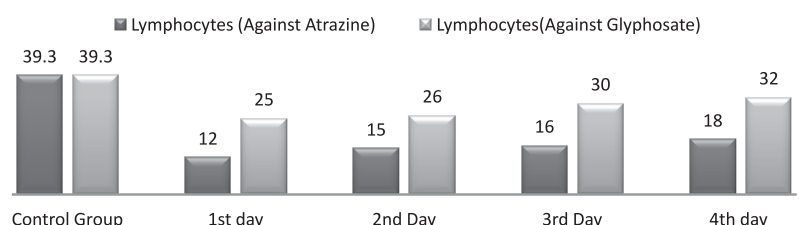

Fig. 6. Comparison of lymphocyte concentrations between control group and treated groups against atrazine and glyphosate.

3.23, 4.33, 5.23, and $6.36 \mathrm{mmol} / \mathrm{l}$, respectively (Fig. 4). $\mathrm{Hb}$ showed different results against both herbicides. Against glyphosate $\mathrm{Hb}$ concentration showed continuous decline while against atrazine $\mathrm{Hb}$ concentration declined, but when compared to the first day of exposure we observed an increase in $\mathrm{Hb}$ concentration. Similarly, decreased $\mathrm{Hb}$ values after acute and sub-acute exposure to deltamethrin have been reported in fingerling European catfish (Silurus glanis), male brood stock (Rutilus frisiikutum), and African catfish (Clarias gariepinus) [45]. The reduction can be related to the decreased RBC number, which indicates hemolysis, hemorrhaging, and reduced erythropoiesis in fish exposed to herbicide.

Platelets concentrations for groups 1-4 were 190,500, $40,666.66,50,333.33$, and 34,666.66 $\mathrm{mmol} / \mathrm{l}$, respectively, against glyphosate herbicide, while against atrazine

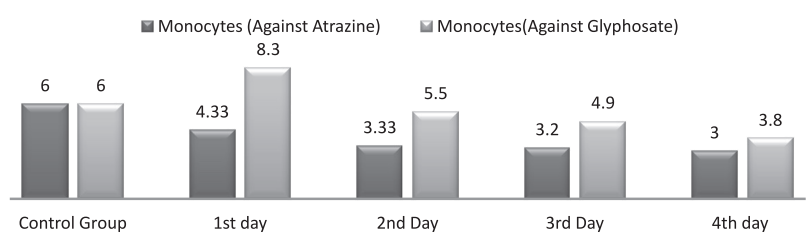

Fig. 7. Comparison of monocyte concentrations between control group and treated groups against atrazine and glyphosate.

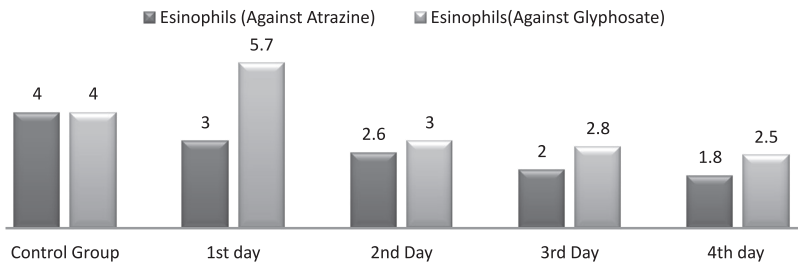

Fig. 8. Comparison of eosinophil concentrations between control group and treated groups against atrazine and glyphosate.

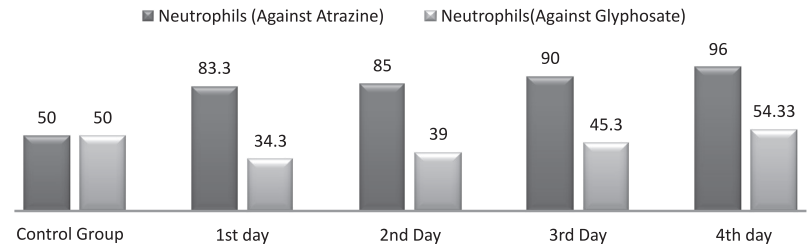

Fig. 9. Comparison of neutrophil concentrations between control group and treated groups against atrazine and glyphosate. platelets concentrations were 20,000, 10,000, 7,033.3, and $5,000 \mathrm{mmol} / \mathrm{l}$, respectively, as shown in Fig. 5. An increase in platelets concentrations against glyphosate was noticed, as was a decline in concentrations against atrazine. [43] found that platelets exhibit significant increases in their number in zinc-treated fish. It should be mentioned that increases in thrombocytes or platelets in treated fish can cause the arrest of any sort of internal bleeding. Moreover, increased numbers of thrombocytes or platelets (being phagocytic in function) may contribute to the strengthening of the phagocytic machinery of the fish under toxicity. Increases in the number of leucocytes occurs due to immunological response. A similar increase in total leucocytes count has been observed by [44].

Against both herbicides the lymphocyte showed a decline in concentration and more decline was observed against atrazine as compared to glyphosate (Fig. 6). Monocytes and eosinophils against glyphosate during the first day increased, while on remaining days declines in concentrations were observed, while against atrazine we saw a continuous decline in concentration (Figs. 7-8). Similarly, neutrophil concentrations against glyphosate decresed, while concentrations observed in neutrophils against atrazine increased (Fig. 9).

\section{Conclusion}

The study suggested that the biochemical and hematological indices of common carp are target parameters for glyphosate and atrazine herbicides. This data verifies that the vicissitudes in biochemical and hematological indices may be used as sensitive biomarkers for animal health evaluation, especially in regions that are naturally affected by herbicides, causing stress in fish on exposure to elevated levels in the water. The present results showed the importance and the effect of herbicide on the natural ecosystem with the alarming rise in pollution over the years. The present study findings help to understand the risk of glyphosate and atrazine herbicide to biochemical and hematological indices of common carp and unveiled that an upturn in RBS, $\mathrm{CH}$, and WBC concentration was observed while SP, LDH, LT, MT, and EP concentrations were decreased against both herbicides. CPK and $\mathrm{Hb}$ concentrations were increased against atrazine, while against glyphosate the concentrations were decreased. PT and NT showed momentous upturn in concentrations against glyphosate, while showing a decline against atrazine as well as both herbicides alter behavior of the common carp during treatment against different doses.

\section{References}

1. XING H., LI S., WANG Z., GAO X., XU S., WANG S., Oxidative stress response and histopathological changes due to atrazine and chlorpyrifos exposure in common carp. Pestic. Biochem. Physiol., 103, 74, 2012. 
2. NWANI C.D., LAKRA W.S., NAGPURE N.S., KUMAR R., KUSHWAHA B., KUMAR S.K. Toxicity of the herbicide atrazine: effects on lipid peroxidation and activities of antioxidant enzymes in the freshwater fish Channa punctatus (Bloch). International Journal of Environmental Research and Public Health, 7, 3298, 2010.

3. RAO G.V.R., RUPELA O.P., RAO V.R., REDDY Y.V.R. Role of biopesticides in crop protection: present status and future prospects. Indian Journal of Plant Protection. 35, 1, 2007.

4. OZMEN M., AYAS Z., GUNGORDU A., EKMEKCI G.F., YERLI S., Ecotoxicological assessment of water pollution in Sariyar Dam Lake. Turkey. Ecotoxicol. Environ. Saf., 70, 163, 2008.

5. ORUC E.O., USTA D., Evaluation of oxidative stress response and neurotoxicity potential of diazinon in different tissues of Cyprinus carpio. Environ. Toxicol. Pharmacol., 23, 48, 2007.

6. BATTAGLIN W.A., KOLPIN D.W., SCRIBNER E.A., KUIVILA K.A., SANDSTROM, M.W., Glyphosate, other herbicides and transformation products in Midwestern streams 2002: agricultural hydrology and water quality. J. Am. Water Resour. Assoc. Middleburg, VA, ETATS-UNIS. 2005.

7. LAKRA W.S., NAGPURE N.S. Genotoxicological studies in fishes: A review. Indian Journal of Animal Sciences.79, 93, 2009.

8. SANBORN M., KERR K.J., SANIN L.H., COLE D.C., BASSIL K.L., VAKIL C. Non-cancer health effects of pesticides: Systematic review and implications for family doctors. Can. Fam. Physician., 53, 1712, 2007.

9. JUREWICZ J., HANKE W. Prenatal and childhood exposure to pesticides and neurobehavioral development: review of epidemiological studies. Int. J. Occup. Med. Environ. Health, 21, 121, 2008.

10. SOLOMON K.R., CARR J.A., PREEZ L.H.D. Effects of atrazine on fish, amphibians, and aquatic reptiles: a critical review. Critical Reviews in Toxicology. 38, 721, 2008.

11. BLAHOVA J., PLHALOVA L., HOSTOVSKY M. Oxidative stress responses in zebrafish Danio rerio after subchronic exposure to atrazine. Food and Chemical Toxicology., 61, 82, 2013.

12. MELA M., GUILOSKI I.C., DORIA H.B. Effects of herbicide atrazine in neotropical catfish (Rhamdiaquelen). Ecotoxicology and Environmental Safety. 93, 13, 2013.

13. TILLITT D.E., PAPOULIAS D.M., WHYTE J.J., RICHTER C.A., Atrazine reduces reproduction in fathead minnow (Pimephalespromelas). Aquat. Toxicol., 99, 149, 2010.

14. KREUTZ L.C., BARCELLOS L.J.G., MARTENINGHE A., DOS S., ZANATTA E.D. Innate immune response of silver catfish (Rhamdiaquelen) exposed to atrazine. Fish Shellfish Immunol., 33, 1055, 2012.

15. SANBORN M., KERR K.J., SANIN L.H., COLE D.C., BASSIL K.L., VAKIL C. Non-cancer health effects of pesticides: Systematic review and implications for family doctors. Can. Fam. Physician., 53, 1712, 2007.

16. JUREWICZ J., HANKE W. Prenatal and childhood exposure to pesticides and neurobehavioral development: review of epidemiological studies. Int. J. Occup. Med. Environ. Health, 21, 121, 2008.

17. RYMUSZKA A., SIWICKI A.K., SIEROSLA W.A. Determination of modulatory potential of atrazine on selected functions of immune cells isolated from rainbow trout (Oncorhynchus mykiss). Centeral European Journal of Immunology. 32, 97, 2007.

18. TIERNEY K.B., SINGH C.R., ROSS P.S., KENNEDY
C.J. Relating olfactory neurotoxicity to altered olfactorymediated behaviors in Rainbow trout exposed to three currently-used pesticides. Aquatic Toxicology. 81, 55, 2007.

19. FATIMA M., MANDIKI S.N.M., DOUXFILS J., SILVESTRE F., COPPE P., KESTEMONT P. Combined effects of herbicides on biomarkers reflecting immuneendocrine interactions in goldfish immune and antioxidant effects. Aquatic Toxicology. 81, 159, 2007.

20. LIONETTO M.G., CARICATO R., GIORDANO M.E., ERROI E., SCHETTINO T. Carbonic anhydrase as pollution biomarker: an ancient enzyme with a new use. International Journal of Environmental Research Public Health. 9, 3965, 2012.

21. TILLITT D.E., PAPOULIAS D.M., WHYTE J.J., RICHTER C.A. Atrazine reduces reproduction in fathead minnow (Pimephalespromelas). Aquatic Toxicology. 99, 149, 2010.

22. NELSON D.L., COX M.M., Lehninger Principles of Biochemistry. $4^{\text {th }}$ ed.; WH Freeman and Co. New York. 1013, 2005.

23. GUYTON A.C., HALL, JOHN E. Guyton and Hall Textbook of Medical Physiology with Student Consult Online Access (11th ed.). Philadelphia: Elsevier Saunders. ISBN 0-7216-0240-1. 2006.

24. ONERM.,ATLIG.,CANLIM. Changes in serumbiochemical parameters of fresh water fish Oreochromisniloticus following prolonged metal $(\mathrm{Ag}, \mathrm{Cd}, \mathrm{Cr}, \mathrm{Cu}$, and $\mathrm{Zn})$ exposures. Environ. Toxicol. Chem, 27, 360, 2008.

25. ATTIA1 K.A., BADAWI A.A.E.L. Biology Department, University College, Umm- Al Qura University, Makkah, Saudia Arabia. Physiology Department, Faculty of Veterinary Medicine, Cairo University, Giza, Egypt. Central Lab. For Aquaculture Res., Abbassa, Abo Hammad, Sharkia, Egypt. Int J ApplSciBiotechnol, 3 (2), 314-321DOI: 10.3126/ijasbt. v3i2.12686. 2015.

26. BINUKUMARI S., VASANTHI J. The Toxic Effect of Pesticide Dimethoate 30\% EC on the protein metabolism of the Fresh water fish, Labeorohita. International journal of current microbiology and applied sciences, 2 (12), 79, 2013.

27. STOYANOVA S., YANCHEVA V., ILIEV I., VASILEVA T., BIVOLARSKI V., VELCHEVA I., GEORGIEVA E. Glyphosate induces morphological and enzymatic changes in common carp (CyprinuscarpioL.) liver. Bulg. J. Agric. Sci. 21, 409, 2015.

28. GANESHWADE R.M. Biochemical Changes Induced by Dimethoate in the Liver of Fresh Water Fish Puntius ticto (HAM). Biological Forum-An International Journal. 3 (2), 65, 2011.

29. MOUSA M.A. Toxicological studies on the effect of machete herbicide on some fish species. Egypt. J. AppLScL., 19, 1, 2004.

30. ORUC E.O., USTA D. Evaluation of oxidative stress response and neurotoxicity potential of diazinon in different tissues of Cyprinus carpio. Environ. Toxicol. Pharmacol, 23, 48, 2007.

31. ABBAS H.H., AUTHMAN M.M., ABUMOURAD I., BADAWY E.L.A. Studies on the effect of thiobencarb herbicide on some biological, physiological, biochemical, histological and genetic aspects of Nile tilapia, Oreochromisniloticus. Egypt. J. Aquat. Biol. \& Fish, 11 (1), 123, 2007.

32. JENKINS F., SMITH J. Effects of sub lethal concentration of endosulfan on hematological and serum biochemical parameters in the carp, Cyprinuscarpio. Bull. Environ. Contam. Toxicol, 70, 993, 2003.

33. DAS P.C., AYYAPPAN S., JENA J.K., DAS M. Acute toxicity of ammonia and its sublethal effects on selected 
haematological and enzymatic parameter of mrigala, Cirrhinusmrigala. (Hamilton). Aquat. Res. 35, 134, 2004.

34. BANAEE M., HAGHI B.N., IBRAHIM A.T.H., Sub-lethal toxicity ofchlorpyrifos on Common carp, Cyprinuscarpio (Linnaeus, 1758): biochemical response. International Journal of Aquatic Biology. 1 (6), 281-288 ISSN: 2322$5270,2013$.

35. BANAEE M., SUREDAA., MIRVAGHEFI A.R., AHMADI K. Effects of Diazinon on Biochemical Parameters of Blood in Rainbow Trout (Oncorhynchus mykiss). Pesticide Biochemistry and Physiology. 99, 1, 2012.

36. BANAEE M., AHMADI K. Sub-lethal Toxicity Impacts of Endosulfan on some biochemical Parameters of the Freshwater Crayfish (Astacusleptodactylus). Research Journal of Environmental Sciences. 5 (11), 827, 2011.

37. RAO J.V. Biochemical alterations in euryhaline fish, Oreochromis mossambicus, exposed to sub-lethal concentrations of an organophosphorus insecticide, monocrotophos. Chemosphere. 65, 1814, 2006.

38. YOUSAFZAI A.M., SHAKOORI A.R. Hepatic responses of a freshwater fi sh against aquatic pollution. Pakistan Journal of Zoology. 43 (2), 209, 2011.

39. LAVANYA S., RAMESH M., KAVITHA C., MALARVIZHI A. Hematological, biochemical and ionoregulatory responses of Indian major carp, Catlacatla during chronic sublethal exposure to inorganic arsenic. Chemosphere. 82 (7), 977, 2011.

40. LI Z.H., VELISEK J., GRABIC R., LI P., KOLAROVA J.,
RANDAK T. Use of hematological and plasma biochemical parameters to assess the chronic effects of a fungicide propiconazole on a freshwater teleost. Chemosphere, 83 (4), 572, 2011.

41. SARAVANAN M., KARTHIKA S., MALARVIZHI A.M., RAMESH. Ecotoxicological impacts of clofibric acid and diclofenac in common carp (Cyprinus carpio) fingerlings: hematological, biochemical, ionoregulatory and enzymological responses. Journal of Hazardous Materials. 195, 188, 2011.

42. SINGH P.A., SINGH S., BHARTIYA P., YADAV K. Toxic effect of phorate on the serum biochemical parameters of the snake headed fish Channa punctatus (Bloch). Advances in Bioresearch. 1 (1), 177, 2010.

43. ISHIKAWA N.M.M.J.T., RANZANI-PAIVA J.V., LOMBARDI, FERREIRA C.M. "Haematological parameters in Nile Tilapia, Oreochromisniloticus exposed to Sub-lethal concentrations of mercury”. Braz. J. Zool, 50, 619, 2007.

44. KUMARI N.M., SING P., RANJAN G. Effect of nickel on haematological parameters of an exotic carp, Cyprinus carpio, during the exposure and recovery periods, Natural Environ. And.Poll. Technology, 3 (4), 491-494. 2007.

45. RAUF A., ARIAN N., Acute toxicity of diazinon and its effects on hematological parameters in the Indian carp, Cirrhinusmrigala (Hamilton). Turk. J. Vet Anim. Sci. 37, $535,2013$. 